\title{
MENGURAI KONSEP PERAN PENGASUH PANTI DALAM REKONSILIASI ANAK YANG BERMASALAH DENGAN TEMAN SEBAYA DI PANTI ASUHAN SHABRI KENDARI
}

\author{
Rosdiana $^{1}$, Tanzil $^{2}$, Bakri Yusuf ${ }^{3}$ \\ ${ }^{123}$ Universitas Halu Oleo \\ Email: rosdiana.kesos@gmail.com
}

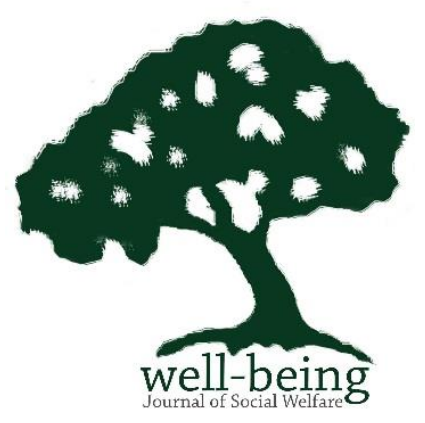

Tujuan penelitian ini adalah untuk mengetahui peran pengasuh panti serta faktor yang mendukung dan menghambat dalam pelaksanaan rekonsiliasi anak yang bermasalah dengan teman sebayanya Di Panti Asuhan Shabri Kendari. Metode penelitian yang digunakan dalam penelitian ini adalah metode kualitatif, sedangkan teknik pengumpulan data yang digunakan adalah teknik wawancara mendalam, observasi, dan studi dokumentasi. Informan dalam penelitian ini adalah lima anak penerima pelayanan, dan orang tua asuh dua orang. Sumber data yang digunakan adalah sumber data primer dan sekunder, selanjutnya hasil penelitian ini dianalisis. Analisis data dalam penelitian ini dilakukan dengan deskriptif kualitatif dan kemudian ditarik sebuah kesimpulan dari data yang diperoleh melalui informan yang relevan dengan penelitian. Hasil dari penelitian ini, pelaksanaan rekonsiliasi anak ada empat cara yang di dalamnya terdapat peran pengasuh panti yaitu: Rekonsiliasi pengungkapan kebenaran, peran pengasuh panti sebagai orang tua penganti. Rekonsiliasi redefinisi identitas sosial, pengasuh berperan memfasilitasi relasi dan komunikasi anak dan menjaga kerahasiaan pribadi anak. Rekonsiliasi keadilan parsial pengasuh berperan memastikan bahwa mekanisme aturan, disiplin dan sanksi sesuai dengan prinsip kepentingan terbaik bagi anak. Rekonsiliasi kesediaan membangun hubungan baru, pengasuh berperan menjaga martabat anak . Dengan faktor yang mendukung tersedianya sarana dan prasarana, adanya area yang luas, dan adanya motivasi anak, dengan hambatan tidak adanya pekerja sosial, anak yang susah diatur, kurangnya ilmu pengetahuan pengasuh panti.

Keyword: peran; pengasuh panti; rekonsiliasi anak

\section{PENDAHULUAN}

Pada era globalisasi saat ini salah satu masalah sosial yang ada di tengah masyarakat adalah masalah sosial anak. Anak adalah bagian yang tidak dapat terpisahkan dari keberlangsungan hidup manusia dan keberlangsungan sebuah bangsa dan negara. Agar setiap anak kelak mampu memikul tanggung jawab, mereka perlu mendapat kesempatan yang seluas-luasnya untuk tumbuh dan berkembang secara optimal, baik fisik, mental maupun sosial. Sebagai negara yang menjunjung tinggi hak asasi manusia. Pemerintah Republik Indonesia menjamin perlindungan anak dan pemenuhan hak-hak anak yang diatur dalam beberapa peraturan, sebagaimana yang ditegaskan oleh konstitusi UndangUndag Dasar 1945.

Undang-Undang No 4 Tahun 1979 tentang Kesejahteraan Anak, menjelaskan bahwa kesejahteraan anak adalah suatu tata kehidupan dan penghidupan anak yang dapat menjamin pertumbuhan dan perkembangan dengan wajar, baik secara rohani, jasmani maupun sosial. Namun demikian pemeliharaan kesejahteraan anak belum dapat dilakukan oleh anak sendiri sehingga tanggung jawab tersebut menjadi tanggungan orang tua, keluarga, masyarakat dan pemerintah.

Berbagai komitmen nasional baik yang berwujud peraturan perundangundangan maupun kebijakan, mengamanatkan bahwa usaha kesejahteraan sosial untuk penyandang 
masalah sosial dilaksanakan oleh pemerintah dan masyarakat. Pemerintah dalam hal ini termasuk pemerintah daerah, dalam menangani masalah sosial anak diperlukan peran masyarakat yang seluas-luasnya, baik perseorangan, keluarga, organisasi keagamaan, organisasi sosial kemasyarakatan, lembaga swadaya masyarakat, organisasi profesi, badan usaha, lembaga kesejahteraan sosial, maupun lembaga kesejahteraan sosial asing demi terselenggaranya kesejahteraan sosial yang terarah, terpadu dan berkelanjutan. Penanganan anak penyandang masalah yang dilakukan oleh pemerintah dan masyarakat di Sulawesi Tenggara dilaksanakan dengan dua sistem, yaitu sistem Panti dan sistem non Panti.

Secara umum dalam kepmensos No. 50/HUK/2004 menjelaskan bahwa Panti asuhan adalah panti sosial yang mempunyai tugas memberikan bimbingan dan pelayanan bagi anak yatim, yatim piatu, anak yang kurang mampu, dan terlantar agar potensi dan kapasitas belajarnya pulih kembali dan dapat berkembang secara wajar".

Lembaga Kesejahteraan Sosial Anak, Yayasan Panti Asuhan Shabri Kendari merupakan suatu lembaga pengganti fungsi orang tua yang memiliki peran dan posisi dalam keluarga. Panti sosial asuhan anak yang memberikan pelayanan kepada anak yatim piatu terlantar dan anak yang ekonominya lemah. Yayasan ini berdiri secara resmi sejak tahun 1980 dengan Akta Notaris Nomor: 28 Tanggal 29 Maret 1980. Namun salah satu kegiatan dari Yayasan ini yakni penyantunan anak Yatim/Terlantar sudah dimulai sejak tanggal 1 agustus 1974, dan telah terdaftar pada jawatan Sosial Provinsi Sulawesi Tenggara sejak tanggal 13 November 1974 Nomor Kes.2/1506/JASOS/1974.

Salah satu tugas pokok Panti Asuhan Shabri adalah meningkatkan SDM dan sebagai pelaksanaan perlindungan sosial bagi anak terlantar usia sekolah dasar sampai dengan usia sekolah menengah umum yang diberikan kepada anak-anak kurang mampu untuk memperoleh pelayanan pendidikan secara gratis. Jumlah secara keseluruhan anak yang berada di Panti Asuhan Shabri menurut Kepala Panti ada 76 anak yang terdiri dari anak perempuan berjumlah 32 orang dan laki-laki berjumlah 44 orang yang tinggal di Panti berstatus sekolah SD berjumlah 29 anak, SMP berjumlah 16 anak dan SMA 31 anak dan ada 14 pengasuh Panti yang membantu anak (Profil Panti Asuhan Shabri Kendari).

Kehidupan di Panti asuhan mengajarkan kita agar hidup dalam kebersamaan, tetapi kebersamaan kadang menimbulkan pro dan kontra pada suatu hal, anak yang seringkali kontra terhadap teman sebayanya kadang tidak dapat mengambil keputusan yang baik di usianya yang masih labil jadi pengasulah yang berperan dalam penyelesaian dan rekonsiliasi anak-anak yang pro tersebut.

Menurut kepala Panti anak-anak yang tinggal Di Panti Asuhan Shabri Kendari ini datang dari berbagai daerah jadi sifatnya pasti berbeda-beda, dalam satu keluarga saja pasti terjadi yang namanya perselisihan antara saudara kandung apalagi anak-anak yang berada di Panti Asuhan Shabri.

Berdasarkan uraian diatas, maka penulis tertarik untuk mengangkat suatu penelitian yang dituangkan dalam bentuk ilmiah dengan judul "Peran Pengasuh Panti Dalam Rekonsiliasi Anak Yang Bermasalah Dengan Teman Sebayanya (Studi Di Panti Asuhan Shabri Kendari)."

\section{METODE PENELITIAN}

Penelitian ini dilaksanakan di Panti Asuhan Shabri Kelurahan Watu-watu, Kecamatan Kendari Barat. Lokasi ini dip ilih atas dasar pertimbangan bahwa Panti Asuhan Shabri Kendari telah menyeleng garakan pembinaan terhadap anak asuh khususnya anak yatim piatu terlantar dan ekonomi lemah sejak tahun 1980 dengan Akta Notaris Nomor: 28 Tanggal 29 Maret 1980. Dengan pengasuhan anak yang melaksanakan pembinaan berdasarkan ketentuan yang berlaku. 
Dalam penelitian ini penulis menggunakan tipe penelitian deskriptif kualitatif, yang mana peneliti berusaha mengkaji, menelaah dan juga dapat menguraikan data yang akan didapatkan di lapangan yakni peranan pengasuh dalam rekonsiliasi anak yang bermasalah dengan teman sebayanya di Panti Asuhan Anak Shabri Kendari.

Penentuan informan dilakukan peneliti menggunakan teknik purposive sampling, yaitu pengambilan sumber data dengan pertimbangan tertentu, misalnya orang tersebut dianggap paling tahu tentang informasi yang peneliti harapkan sehingga akan memudahkan peneliti menjelajahi objek atau situasi sosial tertentu. Dalam sebuah penelitian diperlukan orang-orang yang akan kita pilih sebagai pemberi informasi mengenai data yang kita perlukan. Adapun sumber data dalam penelitian ini terdiri dari Kepala Panti Asuhan Shabri, Tenaga Pengasuh Anak, dan Anak Asuh.

Sumber pengumpulan data dikumpulkan melalui informan dengan mengunakan Data primer dapat bersifat kualitatif atau pernyataan tentang suatu yang menyangkut peranan pengasuh panti dalam rekonsiliasi anak yang bermasalah dengan teman sebayanya di Panti Asuhan Shabri Kendari. Dan Sumber data sekunder adalah data yang diperoleh secara tidak langsung dari informan peneliti, tetapi data di peroleh dari hasil studi dokumentasi. data tertulis, foto dan literatur-literatur yang berhubungan dengan penelitian.

Teknik pengumpulan data yang digunakan oleh penulis dalam penelitian ini adalah observasi/pengamatan, wawancara, dan dokumentasi. Data yang dikumpulkan dalam penelitian ini akan dianalisis secara deskriptif kualitatif yaitu semua sumber data yang diperoleh dilapangan dikumpulkan dan kemudian ditarik kesimpulan berdasarkan jawabanjawaban dari informan yang relevan dengan masalah-masalah dalam penelitian ini.Untuk data primer terlebih dahulu dilakukan tabulasi data dan data kategorisasi/edit (data wawancara dan pengamatan), untuk selanjutnya diinterprestasikan atau dikualitatifkan, hal ini juga dilakukan untuk data sekunder.

\section{HASIL DAN PEMBAHASAN}

\section{Konsep Peranan}

Seorang pakar pekerja sosial, Soetraso (dalam Huraerah, 2011) mendefinisikan peranan sebagai sekumpulan kegiatan alustri yang dilakukan guna tercapainya tujuan yang telah di tentukan bersama antara penyedia dan pe nerima layanan. Sedangkan dalam buku psikologi sosial oleh Abu Ahmadi (2007) menjelaskan bahwa peranan yaitu suatu kompleks pengharapan manusia terhadap caranya individu harus bersikap dan berbuat dalam situasi tertentu berdasarkan status dan fungsi sosialnya.

\section{Konsep Pengasuh Anak}

Pengasuh menurut arti kata dasar asuh yang artinya mengurus, mendidik, melatih, memelihara dan mengajar, kemudian diberi awalan pen-(pengasuh) berarti kata pelatih, pembimbing, jadi pengasuh memiliki makna orang yang mengasuh, mengurus, memelihara, melatih dan mendidik. Menurut Hastuti Dalam sella khairunisa (2010) "pengasuh adalah pengalaman keterampilan dan tanggung jawab sebagai orang tua dalam mendidik dan merawat anak". Sebagaimana (Direktorat pendidikan anak usia dini, 2010) tenaga pengasuh adalah seseorang yang memiliki kemampuan untuk memberikan pelayanan pengasuh dan perawatan kepada anak untuk mengantikan peran orang tua yang sedang bekerja atau mencari nafkah.

Peran pengasuh dalam Budiaharjo (2015) menjelaskan bahwa anak harus mendapatkan pengasuhan dari keluarga, atau keluarga pengganti, maka alternatife terakhir adalah pengasuhan berbasis lembaga kesejahteraan sosial anak atau Panti asuhan sosial anak. Maka Pengasuh harus melaksanakan 
pelayanan pengasuhan sesuai dengan standar yang diterapkan pemerintah yakni.

a. Pengasuh berperan sebagai orang tua pengganti sementara bagi anakanak dan bertaggung jawab untuk memenuhi pemenuhan hak-hak mereka.

b. Pengasuh berperan menjaga martabat anak sebagai manusia, diperlakukan dan dihargai sebagai individu yang utuh, memiliki karakter yang unik serta menjamin anak terhindar dari segala bentuk diskriminasi.

c. Pengasuh berperan memberikan perlindungan bagi anak dari segala bentuk kekerasan dan hukuman fisik.

d. Pengasuh berperan memahami perkembangan anak, melalui perlibatan anak dalam berbagai kegiatan dengan tujuan untuk meningkatkan percaya diri dan membangun konsep diri yang baik, anak perlu berpartisipasi sesuai dengan tingkat kematangan usianya dan kegiatan Panti harus dilakukan dengan pemahaman bahwa masa remaja adalah kunci bagi tahapan sosialisasi sehingga remaja perlu memperoleh ruang dan kesempatan yang fleksibel untuk bersosialisasi secara aman dan bertaggung jawab.

e. Pengasuh berperan memastikan bahwa setiap anak memiliki identitas legal yang jelas, termasuk akta kelahiran dan kartu tanda penduduk (ktp) dan Pengasuh dilarang mengganti identitas asal anak, termasuk nama agama dan etnisitas.

f. Pengasuh berperan memfasilitasi relasi dan komunikasi anak dengan orang tua, keluarga, dan kerabat. Memberikan waktu berkunjung bagi anak bertemu orang tua, keluarga dan kerabat. Membangun kedekatan anak dengan orang tua, keluarga, kerabat dan masyarakat. Hubungan persaudaraan yang baik antara anak-anak di Panti. Relasi yang positif dan pantas antara lakilaki dan perempuan. Relasi individual yang baik dengan pengasuh. Hubungan yang positif dengan pihak luar lembaga yakni guru, teman dan lingkungan sekolah.

g. Pengasuh mendorong partisipasi anak, menghargai pendapat anak, dan melibatkan anak dalam penyusunan dan pelaksanaan aturan untuk penegakan disiplin, memberikan masukan bagi pelayanan Panti serta dalam perencanaan dan pengambilan keputusan pengasuhan, termasuk berapa lama akan tinggal dalam Panti dan tujuan dari penempatan anak.

h. Pengasuh menjamin pemenuhan kebutuhan makan dan pakaian anak, dengan pola makan yang teratur, makanan yang terjaga baik dari kualitas gizi dan nutrisi dengan waktu yang fleksibel sesuai dengan kebutuhan anak. Menu direview bersama pihak yang memiliki kewenangan dalam bidang kesehatan secara regular minimal 6 bulan sekali. Pengasuh menciptakan situasi makan yang menyenangkan. Pengasuh harus memenuhi pakaian untuk setiap anak secara memadai, dari segi jumlah, fungsi, ukuran dan tampilan yang memperhatikan keinginan anak.

i. Pengasuh berperan memastikan pemenuhan hak dan akses anak terhadap pendidikan kesehatan.

j. Pengasuh berperan menjaga kerahasiaan pribadi anak, menjaga semua informasi tentang anak yang sifatnya rahasia dan mengatur sistem untuk memastikan kerahasiaan informasi tersebut serta menghargai privasi anak.

k. Pengasuh berperan menjaga anak dari pekerjaan terburuk untuk anak, termasuk mempekerjakan anak 
pada pekerjaan berbahaya, perbudakan, eksploitasi, dan yang membahayakan kesehatan, keselamatan atau moral anak-anak.

1. Pengasuh berperan memastikan bahwa mekanisme aturan, disiplin dan sanksi sesuai dengan prinsip kepentingan terbaik bagi anak dan sanksi tidak bersifat merendahkan anak.

\section{Konsep Rekonsiliasi Anak}

Dalam Soebijantoro

menjelaskan bahwa rekonsiliasi secara umum dipahami sebagai cara untuk mengakhiri konflik, rekonsiliasi sebagai istilah dan konsep tidak diartikan sama oleh para ilmuwan dan praktisi. beberapa definisi mengartikan rekonsiliasi sebagai suatu peristiwa. Sebagian lagi menyatakan rekonsiliasi sebagai proses dan hasil sekaligus. Beberapa peneliti lainnya beranggapan rekonsiliasi lebih tepat dipandang sebagai pemulihan hubungan.

Selanjutnya menurut Gutman dalam Alexander (2012), rekonsiliasi adalah menciptakan hubungan-hubungan damai secara sejajar diantara antagonis, antagonis sejajar berdasarkan pada kesamaan resiprokal, sikap saling menghargai dan terutama kesepakatan

Berdasarkan pengertian diatas untuk mengakhiri konflik pada anak yang bermasalah dengan teman sebayanya harus adanya sikap saling menghargai dan kesepakatan, dengan ini akan sampai pada tahap pemaafan. pemaafan rekonsiliasi adalah bagian dari proses pemaafan, atau proses transformasi emosi-emosi tertentu, misalnya marah, dendam, menjadi kedekatan, hubungan baik hingga terciptanya etos berdamai. Dengan adanya proses transformasi ini terbukalah kemungkinan untuk memperbaharui hubungan-hubungan yang pernah buruk, dan ini hanya bisa tercapai melalui proses pemaafan (Long dan Brecke 2003)]

Menurut Bar-Tal (2000) dalam Soebijantoro (2012), proses rekonsiliasi harus mengutamakan menyentuh aspek psikologis yang terdalam pada masyarakat. Rekonsiliasi mensyaratkan perubahan-perubahan psikologis mendasar, yaitu proses transformasi dan sikap yang menyokong hubungan yang damai antara pihak-pihak yang bermusuhan.

Proses perubahan etos ini juga harus menyangkut mengenai konsepsi dan harapan tentang tujuan-tujuan masyarakat pada masa mendatang dan mengenai prospek perdamaian dimasa mendatang. Dengan demikian proses pemaafan tidak terjadi begitu saja, tetapi melalui transformasi kesadaran. Long dan Bercke (2003) membagi proses pemaafan dalam empat tahap yaitu:

1. Pengungkapan kebenaran

2. Redefinisi identitas sosial

3. Keadilan parsial

4. Kesediaan membangun hubungan baru

Pada fase pertama, individu atau kelompok yang berkonflik harus mau dan rela menyadari apa yang telah terjadi dimasa lalu. Setiap kelompok yang bertikai harus mau dan mampu menyadarinya. Idealnya proses pengungkapan kebenaran harus terbuka saat melakukan pembimbingan atau advokasi bagi individu yang bermasalah, memang ini akan mempengaruhi psikologi dan reaksi yang akan muncul, merasa malu, bersalah, dan perilaku agresif aktif (marah) maupun pasif (dendam) Atau bisa juga pemaafan. Pilihan untuk memaafkan mengharuskan semua pihak untuk menyadari terlebih dahulu (bukan mengingkari) apa apa yang telah terjadi, siapa yang melakukan, mengapa ia melakukan, apa kesalahanya (North, 1998). Pada fase kedua, rekonsiliasi menghendaki kesediaan kelompok mengubah sudut pandangnya mengenai posisi dan identitasnya sendiri. Redefinisi pasca konflik melibatkan sekaligus faktor kognitif dan emosi. Pada fase ketiga, kelompok-kelompok yang dirugikan sungguh pun berhak untuk mendapatkan keadilan yang setimpal dengan apa yang diperbuat pihak lain 
kepadanya sebelumnya, ataupun mempunyai kesempatan untuk membalas dendam, hendaknya bisa menyadari bahwa keadilan tidak bisa ditegaskan sepenuhnya karna keadilan hanyalah sebatas penegakkan. Pada fase keempat, proses rekonsiliasi harus diakhiri dengan keinginan untuk membuat kontak lebih intens, jika perlu disertai dengan pemaafan secara publik atau secara sosial menawarkan hubungan yang lebih bagus, paling tidak hidup berdampingan secara damai, saling menghormati, dan saling toleran. Proses rekonsiliasi menurut pemaafan ini pada umumnya terjadi fasefase yang diatas, walaupun tidak selalu berjalan berurutan secara satu arah atau berurutan akan berlangsung stimulan dalam saat yang bersamaan dan mencapai berhasilnya rekonsiliasi.

\section{KESIMPULAN}

Berdasarkan hasil penelitian yang dilakukan Di Panti Asuhan Shabri Kendari, Kesimpulan yang dapat diambil sebagai berikut:

\section{Peran Pengasuh Panti Dalam Rekonsiliasi Anak Yang Bermasalah Dengan Teman Sebayanya di Panti Asuhan Shabri Kendari}

Pengasuh Panti harus mampu memerankan berbagai peran yang dibutuhkan demi kelancaran proses pemulihan anak yang bermasalah juga harus mampu menempatkan diri dalam berbagai situasi dan kondisi yang ada. Terdapat banyak peran pengasuh Panti dalam pengasuhan anak yang dilakukan untuk membantu anak/penerima manfaat melalui program yang ada Di Panti Asuhan Shabri Kendari namun terkhusus dalam pelaksanaan rekonsiliasi anak yang bermasalah dengan teman sebayanya Peran pengasuh Panti dalam

a) Rekonsiliasi pengungkapan kebenaran yaitu Pengasuh berperan sebagai orang tua pengganti sementara bagi anak- anak dan bertaggung jawab untuk memenuhi pemenuhan hak-hak mereka Dalam hal ini pengasuh yang sebagai orang tua pengganti wajib menasehati anak supaya anak-anak ini tidak bertengkar dan berselisih karena dalam Panti hidup bersaudara, susah senang bersama, apapun yang di miliki harus berbagi dengan sesama teman, sehingga anak-anak ini mengerti.

b) Peran pengasuh Panti pada redefinisi identitas sosial yaitu Pengasuh berperan memfasilitasi relasi dan komunikasi anak dengan orang tua, keluarga, dan kerabat dan Pengasuh berperan menjaga kerahasiaan pribadi anak, menjaga semua informasi tentang anak yang sifatnya rahasia dan mengatur sistem untuk memastikan kerahasiaan informasi tersebut serta menghargai privasi anak hal ini bahwa pengasuh Panti menjaga anak selalu dalam kondisi baik dan merahasiakan privasi anak asuh

c) Peran pengasuh Panti dalam rekonsiliasi keadilan parsial yaitu Pengasuh berperan memastikan bahwa mekanisme aturan, disiplin dan sanksi sesuai dengan prinsip kepentingan terbaik bagi anak dan sanksi tidak bersifat merendahkan anak. Dengan adanya keadilan parsial seprti yang maksudnya supaya anak-anak asuh bisa saling merasakan apa yang lain rasakan sehingga hal tersebut tidak terus terulang kedepannya.

d) Peran pengasuh Panti dalam pelaksanaan rekonsiliasi pada Kesediaaan membangun hubungan baru yaitu: Pengasuh berperan menjaga martabat anak sebagai manusia, diperlakukan dan dihargai sebagai individu 
yang utuh, memiliki karakter yang unik serta menjamin anak terhindar dari segala bentuk diskriminasi, Pengasuh berperan memberikan perlindungan bagi anak dari segala bentuk kekerasan dan hukuman fisik, Pengasuh berperan memahami perkembangan anak, melalui perlibatan anak dalam berbagai kegiatan dengan tujuan untuk meningkatkan percaya diri dan membangun konsep diri yang baik, anak perlu berpartisipasi sesuai dengan tingkat kematangan usianya dan kegiatan Panti harus dilakukan dengan pemahaman bahwa masa remaja adalah kunci bagi tahapan sosialisasi sehingga remaja perlu memperoleh ruang dan kesempatan yang fleksibel untuk bersosialisasi secara aman dan bertaggung jawab dalam hal ini pengasuh berperan membangun hubungan baru kepada anak yang bermaslah supaya tetap terjaga kesolidaritasannya.

\section{Faktor Yang Mendukung Dan Hambatan Pengasuh Panti}

Adapun faktor yang mendukung dalam pelaksanaan rekonsiliasi anak yang bermasalah dengan teman sebayanya Di Panti Asuhan Shabri Kendari yaitu

a) Tersedianya sarana dan prasarana Panti Asuhan Shabri Kendari ,dimana sarana dan prasaranya adanya sekolah yang disediakan dari Panti Asuhan Shabri dari jenjang SD sampai jenjang SMA, ini mendukung pengasuh dalam rekonsiliasi anak yang bermasalah dengan cara mendidik, membina, dan selalu mengawasi anak-anak Karena selalu berada dalam lingkungan Panti dan sekolah.

b) Adanya area yang lumayan luas, Panti asuhan memiliki gedung sekolah hartati dari SD sampai
SMA, memiliki gedung asrama, mushola dan halaman yang luas sebagai tempat bermain voli bagi anak-anak asuh utuk menjaga kesolidaritasan mereka.

c) Adanya motivasi anak sehingga anak asuh tidak mudah menyerah walaupun adanya masalah dalam Panti asuhan sehingga pengasuh pula dengan mudah rekonsiliasi anak yang bermasalah.

Adapun hambatan yang dirasakan oleh pengasuh Panti ketika sedang melakukan perannya terbagi kedalam tiga kategori yaitu:

a) Hambatan yang berasal dari lembaga/instansi yang dimana tidak adanya pekerja sosialnya Di Panti Asuhan Shabri Kendari.

b) Hambatan yang berasal dari klien/anak yang susah di atur.

Hambatan yang berasal dari diri pengasuh Panti yang merasa memiliki ilmu yang kurang sehingga apa yang diberikan kepada anak asuh masih kurang maksimal.

\section{SARAN}

Berdasarkan temuan di lapangan dan hasil analisa mengenai peran pengasuh Panti dalam rekonsiliasi anak yang bermasalah dengan teman sebyanya Di Panti Asuhan Shabri Kendari, terdapat beberapa hal yang perlu diperbaiki untuk kemajuan keberfungsian anak di masa yang akan datang dan untuk meningkatkan peran serta fungsi dari para pengasuh Panti di Panti Asuhan Shabri. Panti Asuhan Shabri Kendari merupakan Panti yang berada di bawah pengawasan Kementrian Sosial,sebaiknya lebih memperhatikan pengasuh Panti yang terbatas jumlahnya sehingga perlu adanya tenaga pekerja sosial, mengingat pekerja sosial yang ada di Panti asuahn shabri tidak ada. dan juga lebih meningkatkan pelayanan kegiatan keterampilan bagi anak (pendidikan non formal) dengan lebih meningkatkan pemenuhan kebutuhan fasilitas seperti menambahkan fasilitas yaitu komputer, karena jika anak-anak ada keperluan terkait 
dengan tugas dari sekolah mereka tidak perlu keluar lagi dalam Panti.

Kemudian perlu adanya kegiatan pembinaan dan konseling kepada anakanak yang melakukan perbuatan tidak baik seperti anak yang melanggar peraturan dalam Panti, sebaiknya diberikan bimbingan konseling dengan tujuan anak tersebut tidak melakukannya lagi tanpa langsung mengeluarkan dan mengembalikan anak pada orang tuanya. Karena jika anak dikeluarkan dalam keadaan tidak diberi bimbingan moral dan konseling, kemungkinan hal yang sama ia akan lakukan di luar Panti, dan juga perlu adanya alternatif dalam pembinaan kepada anak- anak. Misalnya, Rekreasi, Out Bond dan lain-lain.

\section{DAFTAR PUSTAKA}

Ahmadi, Abu. 2007. Psikologi Sosial. Rineka Cipta. Jakarta

\section{Budiaharjo. 2015. Pendidikan Pengasuhan} Pada Panti Sosial Anak Milik Organisasi Sosial Masyarakat Di DKI Jakarta. Vol 12, NO 1 juni 2014, diketik dari http:/www pendidikanpengasuhan.com

Hirsch, Alxander Keller. 2012 Teorisasi Rekonsiliasi Pasca-Konflik. Pustaka pelajar. Yogyakarta

Huraerah Abu. 2011. Pengorganisasian dan Pengembangan Masyarakat. IKAPI. Bandung

KEPMENSOS No. 50/HUK/2004 Tentang perubahan keputusan mentri kesehatan dan kesejhateraan sosial no. 193/MENKES KESOS/III/2000 tentang standardisasi Panti sosial.

Nazir Moh. 2011. Metode Penelitian. Ghalia Indonesia. Bogor.

Khoirunissa. Sella. (2010), dkk pemenuhan kebutuhan pendidikan anak asuh di Panti sosialasuhan anak. Vol 2. No
1, diketik dar http:/www jurnal pola asuh pdf.com

Soebijantoro,dkk. 2012. Rekonsiliasi konflik antar perguruan silat di medium. Vol 02. No 01. Januari 2012, diketik dari http:/www rekonsiliasi.com

\section{Undang-Undang Dasar Republik Indonesia Tahun 1945}

Undang-Undang Nomor 4 Tahun 1974 Tentang Kesejahteraan Anak 